Original Research

\title{
Factors Influencing the Success of the National Nursing Competency Examination taken by the Nursing Diploma Students in Yogyakarta
}

\section{Yulia Wardani}

Department of Nursing, School of Health Sciences of Panti Rapih, Yogyakarta, Indonesia

\begin{abstract}
Introduction: Yogyakarta is a province with the highest percentage of achievements over the past five years. It is argued that it has been affected by many factors. This study was conducted to analyze the factors that influence the success in the national nursing examination of the 3-year nursing diploma students in Yogyakarta.
\end{abstract}

Methods: This study was a descriptive correlation design with a total sample of 755 participants. The variables in this study were mental preparedness and the learning strategy used by the examinees before the exam (internal factors). This is in addition to the management strategy used three months before the exam, the learning methods used within the 3 -year process and the environment where the exam is done (external factors) and also the results of the national nursing competency examination. The questionnaire used in this study was developed by the researcher with a Cronbach's Alpha $=0.82$. The data was analyzed with the frequency distribution, Pearson correlation and R2 for the determinant analysis unit obtained.

Results: This study found that the management strategy and exam room/environment were significantly correlated with the results of the exam $(\mathrm{p}=0.05)$. The learning methods used were also correlated with the results of the exam $(p=0.00)$. The learning strategies used before the exam was a significant factor influencing the success of the national competency examination with a higher coefficient value.

Conclusion: Various factors are related to the success of the national nursing competency examination in Yogyakarta. This study implies that the nursing diploma management and the students should manage the learning strategies used before the exam to achieve better results in the national nursing competency examination.

\section{ARTICLE HISTORY}

Received: May 5, 2019

Accepted: January 7, 2020

\section{KEYWORDS}

learning strategy; national competency examination; factors

\section{CONTACT}

Yulia Wardani

$\triangle$ danygirlspu@gmail.com $\equiv$ Department of Nursing, School of Health Sciences of Panti Rapih, Yogyakarta, Indonesia

Cite this as: Wardani, Y. (2019). Factors Influencing the Success of the National Nursing Competency Examination taken by the Nursing Diploma Students in Yogyakarta. Jurnal Ners, 14(2), 172-180. doi:http://dx.doi.org/10.20473/jn.v14i2.12229

\section{INTRODUCTION}

The implementation of the Mutual Recognition Arrangement (MRA) affects the dynamics of the Association of South East Asia Nations (ASEAN) and the Economic Community (AJCCN Forum, 2016). The Global Competitiveness Index in 2017-2018 shows that Indonesia was in 36th place from among 137 countries globally (World's Economic Forum, 2018). Nursing and tourism are some of the free flowing services ready to compete in the free market competition. The current global situation of the nursing workforce is experiencing an undersupply of nursing staff (Marc, Bartosiewicz, Burzynka, Chmiel, and Januszewicz, 2018). The increasing elderly population and decreasing number of births, which influences health policies and health care systems around the world, will affect the human resource demand of nursing. To deal with this condition, some nursing institutions should adapt their strategies to manage their institutions. Nurses who graduate within a similar nursing education system who want to work overseas will take a nursing competency examination and gain professional certification or recertification in order to update their professional competencies to meet the standards of the origin country. This certification can be achieved through bridging programs and certain nursing courses. It ends in the nursing licensure examination (Covell, Primeau, Kilpatrick, and St.Pierre, 2017).

Unfortunately, Indonesia, while producing a great number of nurses each year, has not been able to 
fulfill the demands of the market yet. The government should be aware that after five years of the national examination for the health care profession ongoing, it still has a big problem. The facts indicate that from the first results of the examination until 2018, the results did not meet expectations. About half of the students - who came from many different health education institutions who participated in the examination - still failed. The low pass rate of the national nursing examination is a burden for many nursing institutions and the government. Some of the nursing institutions in the West and East provinces of Indonesia even had a 0\% - $25 \%$ passing grade. Another problem is the mental preparedness of the re-taker examinees who have still failed the examination many times. Almost 50\% of the participants in the national competency examination were found to be incompetent (re-taker participants) at the time of the study (PNUK, Nakes, 2018)

This performance still needs to be increased significantly in order to be able to reach a higher level of nursing passing grade in the national examination, thus increasing the level of the competency of the nursing students. A higher level passing grade will reflect the level of competency of the graduate nursing students. If this higher passing grade is achieved well, then hopefully the Indonesian nurses can compete with the other ASEAN countries, particularly Singapore and the Philippines. The Indonesian Ministry of Health is mandating all nurses who work in the healthcare services to have a registration document that can be obtained through the national nursing examination after finishing all credits in the degree program (Indonesian Ministry of Health, 2014).

Responding to this situation, nursing education in Indonesia has changed the curricula into a competence-based curriculum based on Kerangka Kualifikasi Nasional Indonesia (KKNI), or the Indonesian National Qualification Framework, in order to have equal parameters of competency that are synchronous and equivalent in the ASEAN scope. The National Competency Examination for the health profession is an examination held by the National Competency Examination committee. It consists of elements from the Indonesian National Nurse Association, the Association of Nursing Education Institution, the Ministry of Research, Technology, and Higher Education, the Ministry of Health, and stakeholders. This examination is a requirement to obtaining a nursing certificate. It is conducted three times a year in the form of paper-based and computer-based examinations. Every student must pass the examination. The examination is taken after the nursing students finish their education and before they apply for work. The conclusion on the passing grade of the examination is determined by the agreement of the expert panel. They are all wellestablished and independent scientists with over 10 years of professional and multidisciplinary experience in health (Kemenristekdikti, 2016).

The performance and results of the competency examination are influenced by several variables and predictors related to either the internal factors inside of the participants or to the external factors. The internal factors, such as the psychological or mental readiness of the students, the learning strategies used to face the examination several months before until a night before the exam day and the physical conditions of the students while taking the examination are believed to be the important factors affecting the examination score. The demographic profiles of the students such as gender, academic achievements and the cognitive ability of the students, especially their problem-solving ability and critical thinking are also important internal predictors that influence the examination score. Shin, Kim, Suh, Jung, Kim, and Yim (2017) stated that construct analysis and a validity test might be significant contributors that affect success in the national competency examination. In order to have a clear understanding of the question, students need to have ability to understand the test construction in many steps of the case reviews.

Some external factors can also influence success in the nursing competency examination. These factors, such as the role of the management in developing the competency test, the registration process, miscommunications and the absence of specific strategies in preparing the students, need to be explored more seriously in order to achieve the best score in the competency examination performance. Kim, Nikstaitis, Park, Amstrong and Mark (2019) said that some students predicted that they will succeed in the nursing licensure exam because they took review courses, made aggressive use of the practice questions and studied hard. A strategic review is done by many nursing institutions at the end of the nursing program stimuli by the student to collect and form an early understanding of the essential nursing courses. Robert (2018) also supported the statement that an accomplishment in all of the essential nursing subjects will lead the students to achieve a higher grade in the national nursing licensure examination. Palompon, Ong and Banico (2012) found that many variables such as their college entrance examination performance in the IQ test, their college grade point average and their preboard examination performances had a correlation with licensure examination performance. The last two variables significantly predicted their licensure nursing examination score. 
Other external factors include support from their family, peers, friends or classmates, the class room environment where the examination is held, the behavior of the lecturers, and the weather. The quality of the clinical instructors, lecturers and the learning methods provided along the program and the location where the competency examination is held are also important variables that affect the examination process (Okanga, Ogur and Arudo, 2017). Considering that there are so many factors affecting the performance of graduate nurses, especially in the national examination process, the researcher is interested in exploring the variables and predictors that affect the results of the national nursing competency examination of the 3-years nursing diploma in Yogyakarta. Yogyakarta was chosen because it is a province that has always had the highest performance in the nursing competency examination in the country since the first time when the examination was held. Although Yogyakarta has only 9 institutions that offer a nursing diploma, this province is always the best province that achieves the highest score and highest percentage in the national nursing diploma competency examination. It also had the highest passing grade of more than 98\% from 2015 until 2018 (PNUK,Nakes, 2018).

\section{MATERIALS AND METHODS}

This quantitative research used a descriptivecorrelative analytical design. The first description was to determine the demographic profile of the participants, the results of the examination, the mental strategies and examination strategies of the participants, the strategies of the managers in preparing the examination and the environment during the examination. This descriptive process was then followed by the correlative analysis process and the analysis of the impact value of the variables in order to explore the most significant predictors of the examination results more deeply and to see the correlations between and among the variables that affect the results of the national competency examination3-year. The independent variables in this study were mental preparedness, learning strategies, management strategies (preparation of the management), learning methods, and the environment/room where the competency test was held. The dependent variable was the results of the competency examination.

The research was conducted in the Special Region of Yogyakarta, Indonesia, and the target population was all of the students participating in the national competency examination at that time. Through the total sampling technique, 766 students doing the 3year nursing diploma participating in the national competency examination in Yogyakarta were chosen as the sample. The instrument used in this research was a questionnaire that was developed by the researcher consisting of 100 items or statements as follows: 1) The first segment consisted of 20 items exploring the physical, mental, and cognitive
Table 1. The Demographic Profile of the Participants $(\mathrm{N}=755)$

\begin{tabular}{|c|c|c|}
\hline Variable & $\mathbf{N}$ & $\%$ \\
\hline \multicolumn{3}{|l|}{ Gender } \\
\hline Male & 165 & 21.9 \\
\hline Female & 590 & 78.1 \\
\hline \multicolumn{3}{|l|}{ Age } \\
\hline $20-24$ years old & 689 & 91.3 \\
\hline $25-29$ years old & 16 & 2.1 \\
\hline $30-34$ years old & 3 & 0.4 \\
\hline 35 - 39 years old & 13 & 1.7 \\
\hline $40-44$ years old & 23 & 3.0 \\
\hline $45-49$ years old & 11 & 1.5 \\
\hline \multicolumn{3}{|l|}{ Province of Origin } \\
\hline South Sumatera & 14 & 1.9 \\
\hline West Sumatera & 1 & 0.1 \\
\hline Bengkulu & 3 & 0.4 \\
\hline Lampung & 13 & 1.7 \\
\hline Banten & 2 & 0.3 \\
\hline DKI Jakarta & 3 & 0.4 \\
\hline West Java & 7 & 0.9 \\
\hline Central Java & 102 & 13.5 \\
\hline Yogyakarta & 515 & 68.2 \\
\hline East Java & 11 & 1.5 \\
\hline Bali & 22 & 2.9 \\
\hline West Nusa Tenggara & 14 & 1.8 \\
\hline East Nusa Tenggara & 14 & 1.8 \\
\hline West Kalimantan & 14 & 1.8 \\
\hline East Kalimantan & 4 & 0.5 \\
\hline Central Kalimantan & 9 & 1.2 \\
\hline South Kalimantan & 2 & 0.3 \\
\hline North Maluku & 1 & 0.1 \\
\hline Papua & 4 & 0.5 \\
\hline \multicolumn{3}{|l|}{ Senior High School Background } \\
\hline Natural Sciences & 336 & 44.4 \\
\hline Social Sciences & 261 & 34.6 \\
\hline Health vocational high school & 50 & 6.6 \\
\hline $\begin{array}{l}\text { Non-health vocational high } \\
\text { school }\end{array}$ & 108 & 14.3 \\
\hline \multicolumn{3}{|l|}{ GPA } \\
\hline $2.00-2.99$ & 24 & 3.1 \\
\hline $3.00-3.99$ & 731 & 96.9 \\
\hline \multicolumn{3}{|l|}{ Types of housing } \\
\hline Private house/with parents & 493 & 65.2 \\
\hline Boarding house & 210 & 27.9 \\
\hline Rented house & 36 & 4.8 \\
\hline Student dormitory & 16 & 2.1 \\
\hline
\end{tabular}

preparation of the students before taking the national nursing competency examination; 2) the second segment contained 20 items used to explore the learning strategies of the students when facing the examination in which every statement led to the steps and readiness of the students to face the national competency examination; 3) the third segment, consisting of 20 items, showed the strategies of the managers of the study program in preparing the students to do the final exam; 4) the fourth segment of the instrument consisted of 20 items that explored the types of learning method experienced by the students alongside the learning process of the three-year nursing diploma program 
Table 2. The Distribution of the Levels of Mental Preparedness, Learning Strategies, Management Strategies, Learning Methods, and the Environment/Room Used by the Participants $(\mathrm{N}=755)$

\begin{tabular}{lcc}
\hline \multicolumn{1}{c}{ Variable } & N & $\mathbf{~ \% ~}$ \\
\hline Mental Preparedness & & \\
$\quad$ Ready & 395 & 52.3 \\
$\quad$ Not ready & 360 & 47.7 \\
$\quad$ Learning Strategies & & \\
$\quad$ Effective & 397 & 52.6 \\
$\quad$ Ineffective & 358 & 47.4 \\
$\quad$ Management Strategies & & \\
$\quad$ Helpful & 355 & 47.0 \\
$\quad$ Unhelpful & 400 & 53.0 \\
$\quad$ Learning Methods Used & & \\
$\quad$ Suitable & 298 & 39.5 \\
$\quad$ Unsuitable & 457 & 60.5 \\
$\quad$ Condition of the Room & & \\
$\quad$ Conducive & 264 & 35.0 \\
$\quad$ Unconducive & 491 & 65.0 \\
\hline
\end{tabular}

and 5) the last segment had 20 items that explored the condition of the place or room where the examination took place. Every sentence in the questionnaire was filled in by the participants using dichotomy/ binary category scales. This means that the participants could only answer 'yes' or 'no'. Yes had a value of 1 and no had a value of 0 . To make sure that the instruments reliable and valid, a pilot study was performed to test the questionnaire. The results of the reliability test showed that Cronbach's Alpha $=0.82$. Every participant was asked to fill in a document of agreement stating that they were willing to participate in the study.

This study implemented ethical principles of human research such as confidentiality, justice and beneficence. The data collection was carried out in two steps. The first was when the researcher gained a permit for the research from the institutions and when they gathered information from the management of 3-year nursing diploma. The second was at the event briefing for the examination, which was the day before the real examination was held in October 2016. The data was collected by the researcher and a research assistant at Poltekkes Kemenkes, Yogyakarta (a place chosen as a site for the national 3-year nursing diploma examination). The secondary data was collected from the formal announcement of the results of the national nursing competency examination from the committee of the national competency examination. In total, 766 examinees from 9 institutions administering the 3-3year nursing diploma in Yogyakarta filled the questionnaires. After the data were sorted, 755 eligible questionnaires were analyzed; 10 participants did not fill in the questionnaires completely, so the data could not be used. To describe the data through a frequency distribution, the data was then analyzed using SPSS 20 and descriptive analysis. Multiple linear regression was employed to examine the predictors of success in the national competency examination.

\section{RESULTS}

The characteristics of the demographic profile of the participants are presented as follows.

The results of the univariate analysis conducted in Table 1 indicates that 590 (78.1\%) of the participants were female. The most dominant age range was of 20-24 years old for as many as 689 participants $(91.3 \%)$. For province, 515 participants $(68.2 \%)$ came from Yogyakarta and 419 participants (55.4\%) had an educational background of senior high school in a non-science program. The GPAs of 731 participants (99\%) were between 3.00 and 3.99 . As many as 493 participants (65.2\%) stayed in their parents' house.

The results regarding the variables that affect the students when facing the examination are presented in the table below. Table 2 shows the predictors affecting the results of the examination. In terms of the mental preparedness of the participants, 395 participants (51.3\%) said that they did not feel ready to take the examination while 397 participants (52.6\%) used good learning strategies before the exam. On the other hand, 400 institutions (53\%) had bad management when preparing for the examination. In addition to this, 457 participants $(60.5 \%)$ used bad learning methods in their 3-year study in campus and 491 places $(65 \%)$ or the rooms used for the examination were unconducive.

After the demographic profile of the participants was tabulated, the data on the correlation of the results of the national nursing competency examination with mental preparedness, learning strategies, management strategies, and learning methods in the bivariate statistical data has been presented as follows.

From Table 3, it can be seen that the variable of learning strategies has a significant correlation with the mental preparedness of the participants when facing the examination with a $\mathrm{p}$ value $=.01$. The correlation exists at the moderate level with a value of $\mathrm{r}=.092 *$. The learning strategies also have a significant correlation with the preparations performed by the director of the 3-year nursing diploma program with a p-value $=.000$ and an $\mathrm{r}$ value $=.225^{* *}$ The data also shows that the variable of the environment during the examination also has an important role in the success of the students facing the competency test. This variable is significantly correlated with mental preparedness with a $\mathrm{p}$ value $=.000$ and an $\mathrm{r}$ - value $=.144^{* *}$, along with the learning strategies $(\mathrm{p}$ value $=.000$ and $\mathrm{r}$ value $=.246^{*}$ ), management strategies ( $p$ value $=$, 000 and $r$ value $\left.=, 255^{* *}\right)$ and learning methods ( $\mathrm{p}$ value $=.000$ and $r$ value $\left.=.476^{* *}\right)$. The results show that the learning strategies before the examination are accepted as the dominant predictor affecting the nursing competency examination. 


\section{DISCUSSION}

This study has identified that the extrinsic factors correlated with success in the national nursing competency examination are management capability, the learning methods used in the learning process and the environment where the exam is done. The first extrinsic factor is the ability of the managers/directors of the 3-years nursing diploma program in preparing the students from the first semester through to the last semester. These abilities include their inspirational value, enthusiasm, the clarity of the materials used, the plan, the organizational skill materials, the method of learning, and the method of judging and evaluating the learning processes. The capabilities of the managers in strengthening the learning strategies (including the learning processes and the accurate use of learning methods/strategy) are important keys to passing the final competency examination. Nursing managers are also required to be advanced in terms of providing good facilities and infrastructures in the learning process, to employ up-to-date information technology and to update the learning resources used. Pence and Wood (2018) underline that using software and being skillful at managing information technology in the examination will also lead the students to success in the examination, especially in the computer-based test (CBT) examination. Murphy, Goossen, and Weber (2015) also said that educators should have a vision to focus on confirming what informatics competencies are applicable and needed for helping the students in their study and their examination.

The other ability of the manager is planning, managing, and evaluating the learning process of the lecturers. Okanga, Ogur, and Arudo (2017) emphasize that the experience of the faculty has a significant correlation with success in the competency examination. McDonald (2017) adds that nursing educators should provide the students with many opportunities to master the knowledge required for the licensure. Finkelman (2017) also adds that lecturers should be able to serve as a partner for the managers in preparing the nurses for the future.

Pulito (2017) states that in order to be successful in the licensure/competency examination, deep learning is important. Deep learning can be achieved by choosing suitable and accurate learning methods. The deep learning level of the students will be affected by the style of the nursing management used to direct the faculty in teaching and constructing the evaluation/examination. Learning methods are how a person learns something as a part of achieving a certain competency and they are usually designed by the lecturers to achieve a learning outcome in particular course/subject (Mc Donald, 2017). Stojanovic et all (2018) said that students need professional help and support to increase their understanding of some clinical nursing subjects. This idea is supported by Quin, Smolinsky and Peters (2018) who emphasized the role of the nursing faculty is to take steps to prepare the nursing students for success on this difficult examination. The role of the nursing lecturer starts at the beginning of the nursing program and it is focused on the fundamental nursing courses through to the advanced nursing courses at the end semester of the program. The mastery in clinical nursing subject through appropriate learning methods designed by the lecturers and clinical instructors will build a good understanding and mental capacity in the students. Proper learning methods utilized from

Table 3. The Correlation of Mental Preparedness, Learning Strategies of the Students, Management Strategies, Learning Methods and the Environment (Room Condition) with the Results of the National Nursing Competency Examination in Yogyakarta

\begin{tabular}{|c|c|c|c|c|c|c|c|}
\hline & & $\begin{array}{c}\text { Examination } \\
\text { results }\end{array}$ & $\begin{array}{c}\text { Mental } \\
\text { preparedness }\end{array}$ & $\begin{array}{l}\text { Learning } \\
\text { Strategies }\end{array}$ & $\begin{array}{l}\text { Management } \\
\text { Strategies }\end{array}$ & $\begin{array}{l}\text { Learning } \\
\text { Methods }\end{array}$ & $\begin{array}{l}\text { Enviro } \\
\text { nment }\end{array}$ \\
\hline Results of the & Pearson & 1 & -.05 & .06 & .05 & .02 & .05 \\
\hline \multirow[t]{2}{*}{ Examination } & Correlation & & & & & & \\
\hline & Sig.(2-tailed) & & .14 & .06 & .11 & .44. & .12 \\
\hline Mental & Pearson & -.05 & 1 & $.09 *$ & .03 & $.15^{*}$ & $.14^{*}$ \\
\hline \multirow[t]{2}{*}{ Preparedness } & Correlation & & & & & & \\
\hline & Sig.(2-tailed) & .14 & .14 & .01 & .28 & .00 & .00 \\
\hline Learning & Pearson & .06 & $.09 *$ & 1 & $.22 *$ & $.21^{*}$ & $.24^{*}$ \\
\hline \multirow{2}{*}{ Strategies } & Correlation & & & & & & \\
\hline & Sig.(2-tailed) & .06 & .01 & & .00 & .00 & .00 \\
\hline Management & Pearson & .05 & .03 & $.22 *$ & 1 & $.20^{*}$ & $.25^{*}$ \\
\hline \multirow{2}{*}{ Strategies } & Correlation & & & & & & \\
\hline & Sig.(2-tailed) & .11 & .28 & .00 & & .00 & .00 \\
\hline Learning & Pearson & .02 & $.15^{*}$ & $.21^{*}$ & $.21^{*}$ & 1 & .47 \\
\hline \multirow[t]{2}{*}{ Methods } & Correlation & & & & & & \\
\hline & Sig.(2-tailed) & .44 & .00 & .00 & .00 & & .00 \\
\hline \multirow[t]{3}{*}{ Environment } & Pearson & .05 & $.14^{*}$ & $.24^{*}$ & $.25^{*}$ & .47 & \\
\hline & Correlation & & & & & & \\
\hline & Sig.(2-tailed) & .12 & .00 & .00 & .00 & .00 & 1 \\
\hline
\end{tabular}

* The correlation is significant at the 0.05 level (2-tailed)

**The correlation is significant at the 0.01 level (2-tailed) 
first year will increase their verbal and critical thinking skills. The capability to verbalize and understand some of the courses critically builds the mental and emotional capabilities of the students. Suitable and accurate learning methods can cultivate curiosity and their manner of being proactive and communicative. Students can also learn to develop their arguments and reasoning, and ability to see correlations (associations), including the ability to see cause and effect. Therefore, the management skills used to arrange their learning methods are needed.

The management skills could also cover the management activity, person, finances and facilities of the successful exam. Park et al (2017) states that the quality of the question items in the examination is influenced by the methods used to develop the test items. Thus, it needs there to be workshops, brainstorming, verification, and content validity from the experts in order to create quality question items. The nursing education field in Indonesia has enforced many nursing institutions to allow them to have the capability to develop items or questions as part of the basic material of the examination package. For reference, one package of items/questions in the examination book consists of 180 items. After the lecturers write the question items, professional nurses review the questions and send them to the panel expert meeting for them to determine the national passing grade. The quality of the test items determines the quality of the test item package. If the quality of the test items improves, then the possibility of having a good passing grade will increase and thus their chance to pass the exam will be higher.

Shin, Kim, Suh, Jung, Kim, and Yin (2017) explain that management should also consider using simulators or a standardized patient-based method as the most suitable format to increase the students' understanding of the patients' condition. Simulations and patient-based methods in a nursing laboratory practicum or in a clinical nursing setting, such as a hospital and primary health care services, will increase the nursing students' communication abilities and nursing care skills, especially when conducting a nursing assessment about the patients' health problems. Communication, critical thinking, clinical judgment, and competency in relation to their nursing skills/procedures are the key components for success in the nursing competency examination. Critical thinking and clinical judgment are very important skills for nursing students.

The second factor that influenced the results of the examination was the learning methods used by the lecturers in the teaching and learning process. Unsuitable learning methods in the process of education (from the first year up until the third year of the nursing diploma program) leads to failure when doing the competency examination. Some of the learning methods used in nursing education that emphasize critical thinking and clinical judgment are case studies, simulations, problem-based learning, project based learning, debriefing, the ability to reflect, peer review scenarios, writing skills and clinical experience/experimental (Kaddaura, Flint, Van Dyke,Yang and Chiang, (2017), Synder (2018) and Caputi (2019)). Zapko et all (2018) emphasizes that serial simulation and having the student's experience a simulation more than once in consecutive years is the best way to increase their clinical practice in the context of nursing education. On the other hand, a lack of experience in using the learning methods focused on student activities (students centered learning), poor case study methods, and a lack of ability and clinical practices will blunt the abilities of the students in terms of making good inferences and reflecting low critical thinking and clinical judgment skills.

It is urgent to reform the nursing program by enhancing the learning methods in terms of clinical judgment and critical thinking. These skills can be achieved through practicing and applying clinical judgment and critical thinking in some thinking competencies. Hence the case study method and real practices in the real field become important factors in these processes, but not all students can generate the meaning of the experience well. In addition, the satisfaction of the students when they engage in experiential learning in the clinical practice area can increase their self-confidence and their ability to resolve their duties and tasks in the examination. Cowen, Hubbard, and Hancokck (2018) identify that having enough experience to communicate effectively with patients and other health professionals, and their experience of many skills/nursing procedures and observations through clinical courses, will increase their critical thinking and clinical judgment.

The third extrinsic factor that was correlated with success in the nursing examination results was the environment where the exam was done. A conducive environment is a significant factor in terms of increasing the mental preparedness of the examinees which will lead to success in the examination (Sanches, Costa, Agea, Izguerdo, and Rodriquez (2018). The environment or the room for the examination must be well prepared and meet the standards as follows: the room should have good circulation, and the distance between the students should at least be $1 \mathrm{~m} 2$. The room must also have a clear and visible clock/timer that can be seen by all of the participants during the examination (Pnuknakes, 2018). In addition, the room should facilitatee a good, calm, and conducive environment, which means that the room should be quiet, as well as being clean, and comfortable with enough lighting and ventilation. Good circulation will facilitate the examinees in terms of having enough oxygen. The oxygen inhaled will be distributed via the blood flow in the body including to the brain of the person. This will increase the brain's metabolic rate and this will increase the work of the brain in terms of 
concentrating, recall and memorizing, in addition to understanding and reasoning in the examination. The cognitive activities in the brain contribute to the mental preparedness of the examinees. This mental state in the examination is very important to attain success.

Another standard of the environment refers to clear directions and information about the building which will affect success in the examination. When the examinees do not know the location or the room for the test, they will be confused and anxious. Moreover, when the examinees are late and get lost, they might panic and be more stressed. The anxiety and panic will affect their mental cognitive capacity and capability to understand the test which will influence the results of the examination. The position of the toilet is also important. The examinees should know the location of the toilet. The anxious feeling of the examinees while they are taking the examination will trigger them to urinate more often than usual. The location, cleanliness, and comfort of the toilet will help them to reduce their tension. Appropriate lockers for storing their goods, including handphones, is also an important environmental factor that contributes to success in the exam indirectly (Pnuknakes, 2018). In fact, on the day of the examination, the examinees often find that the room is still dirty and hot because of poor ventilation, poor lighting and noise. The noise sometimes comes from the neighborhood of the campus such as the music from a wedding party, motorcycles on the main road, and building construction going on around the campus. The noise will disturb the concentration of the examinees and this will influence the results of the exam indirectly. They cannot concentrate on the examination. Hence, the environment will influence the results of the competency examination indirectly.

The intrinsic factors that were found in this study include mental status and the learning strategies before the exam were used by the examinees. The good mental status of students will decrease their anxiety as well as expand and strengthen their personal competency when the nursing students face the examination. Good psychological wellbeing and emotional security affects cognitive capacity and this can lead to better achievements in the examination. When the students have mental preparedness to face the examination, the chance for them to be successful in the competency test will be higher. Students need help and support to expand and strengthen their psychological wellbeing in terms of improving the level of their competencies. Sanchez, Costa, Agea, Izquierdo, and Rodriquez (2018) explained that social-emotional competencies consist of communication skills, the ability to cope with stress, and engagement in both learning activities and self-efficacy. The process of building their critical thinking and clinical judgment in accurate and suitable learning methods correlates with the mental construction of the nursing students. Nursing students who have a firm mental capacity will have a good emotional security and sense of psychological wellbeing. Psychological wellbeing is an important factor in the examination. Some aspects of psychological wellbeing include good motivation, confidence, the state of being free of panic and anxiety, and the willingness or strong desire to pass the examination. The examinees should be free from anxiety because this will influence their performance in the examination (Stojanovic et all, 2018). Students who have good motivation to become nurses will do their best to pass the examination. The higher their motivation, the better the results of the examination. A person with good motivation will have more enthusiasm and effort and they will struggle more to graduate as soon as possible and to pass the final competency examination. The calling to become a professional nurse and the desire to serve humanity is the highest motivation needed to attain good results in the nursing examination and finally, to become a professional nurse.

Another intrinsic factor was the learning strategies used when facing the exam. It refers to the strategies used by the nursing students to prepare themselves to face the examination from three months up until the day before the competency examination. The learning strategies chosen by the students are a kind of intrinsic factor that can be very specific and personal in the short-term before the examination. Learning only some days before the examination will not fully help the students to pass the nursing competency test. Individuals who use good learning strategies to face the examination are slightly higher in terms of result than those who have poor learning strategies. A few students still did not understand the tips and tricks used to pass the examination. Trying to learn all of the materials in only one night is not a smart strategy. Instead, students can have a course resume, discuss the test questions in a group, attend nursing review classes, and try to answer the test questions on the computer (CBT test questions).

Most students will attend the review class delivered by the management on a very strict schedule several weeks before the examination. Kim, Nikstaitis, Park, Amstrong and Mark (2019) said that some students predicted that they would succeed at the nursing licensure exam because they took review courses, which makes aggressive use of practice questions paired with studying hard. The Health Education System Inc (HESI) test is frequently used as a standardized test in nursing programs. Many students stated that the review course provided by HESI is helpful for achieving a higher passing grade in the nursing licensure examination. Taking review courses seems to be rarely done in Indonesia. The lecturer gave the questions before the exam happened. Some institutions gave them within a week, some within one, two or three months. At the end of the review session, the student did their test taking package and some of them used a computerbased test. The student should be afforded many opportunities to engage in remediation, test taking 
and any other support associated with tutoring. These question review methods helped the students to deal with the questions and as a result, they got a higher passing grade in the nursing exam.

Robert (2018) also supported the finding that there was a significant correlation between the preadmission examination scores and success in the NCLEX-RN (National Council Licensure Examination - Registered Nurse) on the first attempt. Program completion had also a positive correlation with their pre-admission science grade and HESI score. Students who had a higher grade in their preadmission science course were significantly accomplished in all of the essential nursing subjects and this leads them to achieve a higher grade in the national nursing licensure examination. Czekanski, Mingo and Piper (2018) noted that the preparation strategy for success in the nursing licensure examination consists of at least content review and test-taking strategy. A content review will lead the student to have more of a deep understanding of the essential nursing subjects and it will stimulate their critical thinking and clinical judgment when answering the questions. The test-taking strategy will sharpen the student's skills in terms of managing their time, choosing the best answers and managing stress alongside the examination processes themselves. The preparation reviewstrategy needs to begin from the early semester of the nursing program and continue until after program completion. The learning strategy will improve the students' understanding of the test questions. The better the learning strategies used by the students, the better their mental preparedness and psychological well-being, thus better results in the examination can be achieved.

\section{CONCLUSION}

This study concludes that the factors that influence the success of the nursing students in achieving high results in the nursing competency examination are the learning methods used in the 3-year nursing program, the environment (conducive rooms/places where the examination is held, the direction of the building, and a comfortable room), the strategies of the nursing diploma managers/directors in preparing the examination, and the learning strategies employed by the students from three months up until the day before the examination. The factors of mental preparedness and the learning strategies used from the first semester until the last semester are also important factors that contribute indirectly to success in the national competency examination.

The learning strategies used should be considered a critical aspect in achieving the best results in the national nursing exam. The study then recommends that the nursing students who take the competency examination should have effective learning strategies (personally or institutionally) implemented at least three months before the examination. The institution should improve the learning methods taught during the 3-year nursing program, have a special preparation strategy or treatment available before the examination, and provide a conducive environment/room for the examination which meets the standards as a place of examination.

\section{REFERENCES}

Caputi, L. J. (2019). Reflections on the Next Generation NCLEX with Implications for Nursing Programs. Nursing Education Perspectives (Wolters Kluwer Health), 40(1), 2. https://doi.org/10.1097/01.NEP.000000000000 0439

Cormack, C. L., Jensen, E., Durham, C. O., Smith, G., \& Dumas, B. (2018). The 360-degree evaluation model: A method for assessing competency in graduate nursing students. A pilot research study. Nurse Education Today, 64, 132-137. https://doi.org/10.1016/j.nedt.2018.01.027

Covell, C. L., Primeau, M.-D., Kilpatrick, K., \& StPierre, I. (2017). Internationally educated nurses in Canada: predictors of workforce integration. Human Resources For Health, 15(1), 26. https://doi.org/10.1186/s12960-017-0201-8

Dean J, Fischer S, Saint Petersburg Junior Coll. F. Nursing Predictors Study, Phase One. [serial online]. July 20, 1992;Available from: ERIC, Ipswich, MA. Accessed October 13, 2017.

Doe, P. F., Oppong, E. A., \& Sarfo, J. O. (2018). Students' Demographic, Academic Characteristics and Performance in Registered General Nursing Licensing Examination in Ghana. European Journal of Contemporary Education, 7(1), 73-81. Retrieved from http://search.ebscohost.com/login.aspx?direct=t rue \&AuthType=cookie,ip,cpid\&custid=ns134184 $\& \mathrm{db}=$ eric $\& A N=E J 1172931 \&$ site $=$ ehost live \&scope=site

Eyikara, E., \& Baykara, Z. G. (2017). The Importance of Simulation in Nursing Education. World Journal On Educational Technology: Current Issues, 9(1), 2-7.

Finkelman (2017). Professional Nursing Concepts: Competencies for Qualaity Leadership. Jones \& Bartlett Learning.

Murphy,J., Goossen, W.,\& Weber,P (2017). Forecasting Informatics Competencies for Nurses in the Future of Connected Health. IOS Press, Amsterdam, Berlin, Washington, DC

Kaddoura, M. A., Van Dyke, O., \& Yang, Q. (2017). Correlation Between Critical Thinking Skills and National Council Licensure Examination for Registered Nurses Success in Accelerated 
Bachelor Nursing Students. Teaching \& Learning in Nursing, 12(1), 3-7. https://doi.org/10.1016/j.teln.2016.08.004

Kaddoura, M. A., Flint, E. P., Van Dyke, O., Yang, Q., \& Chiang, L.-C. (2017). Academic and Demographic Predictors of NCLEX-RN Pass Rates in First- and Second-Degree Accelerated BSN Programs. Journal of Professional Nursing, 33(3), 229-240. https://doi.org/10.1016/j.profnurs.2016.09.005

Kavanagh, J. M., \& Szweda, C. (2017). A Crisis in Competency: The Strategic and Ethical Imperative to Assessing New Graduate Nurses' Clinical Reasoning. Nursing Education Perspectives (Wolters Kluwer Health), 38(2), 5762.

https://doi.org/10.1097/01.NEP.000000000000 0112

Mcdonald (2017). Guide to Assessing Leraning Outcome. 4th Ed. Jones \& Bartlett Learning.

Park, In Sook, Yeon Ok Suh, Hae Sook Park, So Young Kang, Kwang Sung Kim, Gyung Hee Kim, YeonHee Choi, and Hyun-Ju Kim. 2017. "Item Development Process and Analysis of 50 CaseBased Items for Implementation on the Korean Nursing Licensing Examination." Journal Of Educational Evaluation For Health Professions 14 (September): 20. doi:10.3352/jeehp.2017.14.20.

Pence, J., \& Wood, F. (2018). Using ComputerAdaptive Quizzing as a Tool for National Council Licensure Examination Success. Nursing Education Perspectives (Wolters Kluwer Health), 39(3), 164. https://doi.org/10.1097/01.NEP.000000000000 0289

Pnuknakes (2018). Blueprint uji kompetensi program diii keperawatan. Https://ukperawat.ristekdikti.go.id/index.php/p rosedur_pendaftaran

Pnuknakes (2018). Pedoman persiapan uji kompetensi nasional program studi diii keperawatan. https://drive.google.com/drive/folders/1JQBYES WUZBWlk_EBj0UaxXs2c8GbSptq

Pulito, J. (2017, January 1). Associate Degree Nursing Graduates Perceptions of NCLEX Performance. ProQuest LLC. ProQuest LLC. Retrieved from http://search.ebscohost.com/login.aspx?direct=t rue \&AuthType=cookie,ip,cpid \& custid=ns134184 $\& \mathrm{db}=$ eric\&AN=ED580066\&site $=$ ehost live \&scope $=$ site
Okanga, A. A., Ogur, J. O., \& Arudo, J. (2017). Institutional Characteristics Influencing Bachelor of Science Nursing Student Performance in the Nursing Council of Kenya Licensure Examinations in Kenya. Journal of Education and E-Learning Research, 4(1), 28-36. Retrieved from http://search.ebscohost.com/login.aspx?direct=t rue\&AuthType=cookie,ip,cpid \& custid=ns134184 $\& \mathrm{db}=$ eric $\& A N=E J 1148429 \&$ site $=$ ehost live \&scope $=$ site

Quinn, B. L., Smolinski, M., \& Peters, A. B. (2018). Strategies to Improve NCLEX-RN Success: A Review. Teaching \& Learning in Nursing, 13(1), 18-26. https://doi.org/10.1016/j.teln.2017.09.002

Ristekdikti, (2016). Panduan Pelaksanaan Uji Kompetensi Program Diploma III Kebidanan, Diploma III Keperawatan dan Profesi Ners April Tahun 2016

Sánchez Expósito, J., Leal Costa, C., Díaz Agea, J. L., Carrillo Izquierdo, M. D., \& Jiménez Rodríguez, D. (2018). Socio-emotional competencies as predictors of performance of nursing students in simulated clinical practice. Nurse Education In Practice, 32, 122-128. https://doi.org/10.1016/j.nepr.2018.07.009

Shin, S. J., Kim, Y. K., Suh, S.-R., Jung, D. Y., Kim, Y., \& Yim, M. K. (2017). Perception survey on the introduction of clinical performance examination as part of the national nursing licensing examination in Korea. Journal of Educational Evaluation For Health Professions, 14, 26. https://doi.org/10.3352/jeehp.2017.14.26

Snyder, T. L. (2018, January 1). The Relationship between Admission Requirements, Academic Performance Measures and Undergraduate Nursing Student Success. ProQuest LLC. ProQuest LLC. $\quad$ Retrieved from http://search.ebscohost.com/login.aspx?direct=t rue \&AuthType=cookie,ip,cpid \&custid=ns134184 $\& \mathrm{db}=$ eric $\& A N=E D 587641 \&$ site $=$ ehost live \&scope $=$ site

Stojanovic, G., Vasiljevic-Blagojevic, M., Stankovic, B., Terzic, N., Terzic-Markovic, D., \& Stojanovic, D. (2018). Test Anxiety in Pre-Exam Period and Success of Nursing Students. Serbian Journal of Experimental \& Clinical Research, 19(2), 167174. https://doi.org/10.1515/sjecr-2017-0060

World Economic Forum (2018). The Global Competitiveness Report 2018. Retrive from reports.weforum.org/global-competitivenessreport-2018/dowloads/ 